\title{
Two new species of Sundarion (Hemiptera: Membracidae: Darninae) and taxonomic notes on two congeneric taxa
}

\author{
Antonio J. Creão-Duarte' ${ }^{1}$ \& Albino M. Sakakibara²
}

\begin{abstract}
'Departamento de Sistemática e Ecologia, Universidade Federal da Paraíba. 58059-900 João Pessoa, PB, Brazil. E-mail: creaoduarte@dse.ufpb.br

${ }^{2}$ Departamento de Zoologia, Universidade Federal do Paraná. Caixa postal 19020, 81531-980 Curitiba, PR, Brazil.E-mail: amsakakibara@pq.cnpq.br
\end{abstract}

\begin{abstract}
Two new species of Sundarion Kirkaldy, 1904 - Sundarion flavopiceum sp. nov. (from Brazil, state of Pará, Serra Norte) and Sundarion marmoratum sp. nov. (from French Guiana, Montagne des Chevaux) - are described. The first species differs from S. flavum (Fairmaire, 1846) in having smaller supra-humeral horns, and being dark brown with a large yellow spot on each side of the posterior process. In this aspect, it resembles Alcmeone picea (Fairmaire, 1846). The second species is similar to S. flavum except for being variegate yellowish-brown. Taxonomic comments are provided for S. notabile Souza \& Rothéa, 2005, which was previously known only from males, and for S. compressicornis (Fairmaire, 1846) comb. nov., originally described in Hemiptycha Germar, 1833 and latter transferred to Hemikyptha Metcalf, 1927. New geographical distribution records are provided for both species.
\end{abstract}

KEY WORDS. Auchenorrhyncha; Cicadomorpha; Darnini; taxonomy; treehoppers.

STÅL (1867) erected Pyranthe, which was characterized as follows: "Head triangular, ocelli closer to each other than to eyes; thorax with horns of variable size, each above lateral angles; posterior process descending gradually, not concealing forewings, and terminating before the apex". Subsequently STÅL (1869) redefined the genus to include: Hemiptycha flava Fairmaire, 1846, H. longicornis Fairmaire, 1846, H. flavomarginata Fairmaire, 1846, H. chilensis Spinola, 1852, H. bimaculata Fairmaire, 1846, Pyranthe laticornis Stål, 1869, H. alata Fairmaire, 1846, Pyranthe auriculata Stål, 1869, H. picea Fairmaire, 1846, Smilia xanthographa Germar, 1835, and H. placida Germar, 1835. Butler (1878) designated Hemiptycha flava Fairmaire, 1846 as the type species of Pyranthe Stål, 1867 and transferred H. picea Fairmaire, 1846 to Alcmeone Stål, 1867. KIRKALDY (1904) proposed the name Sundarion in substitution to Pyranthe, which was previously occupied in Tettigonidae.

FunkHouser (1927) catalogued 13 species in Sundarion: S. acaciae (Berg, 1883), S. alata (Fairmaire, 1846), S. apicalis (Germar, 1835), S. auriculata (Stål, 1869), S. bimaculata (Fairmaire, 1846), S. brunniventris (Fairmaire, 1846), S. chilensis (Spinola, 1852), S. flava (Fairmaire, 1846), S. flavomarginata (Fairmaire, 1846), S. frustratoria (Berg, 1883), S. laticornis (Stål, 1869), S. longicornis (Fairmaire, 1846), and S. xanthographa, (Germar, 1835). Funkhouser (1940) added one more species from Peru, Sundarion nigromacula. Metcalf \& Wade (1965) reduced the number of known species (14) to only eight, synonymizing three $(P$. acaciae $=S$. apicalis, $P$. laticornis $=S$. bimaculatum, $H$. longicornis $=S$. flavum), and transferring three to another genus (P. chilensis, $P$. frustratoria, and $S$. xanthographa, to Callicentrus Stål, 1869). McKamey (1998) listed the same eight species and added S. achantocornus Fonseca \& Diringshofen, 1969. Souza \& Rothéa (2005 in CreÃo-Duarte et al. 2005) described four new species, two from Costa Rica and two from Brazil, respectively: $S$. compactum, S. costaricense, S. notabile, and S. rubricatum. SAKAKIBARA \& CREÃo-DuARTE (2006) published a taxonomic note concerning the species of Sundarion described by C. Berg and M. Spinola, reinstating two of them, S. acaciae (Berg, 1883) and S. chilense (Spinola, 1852), which were considered by Metcalf \& WADE (1965) and McKAMEY (1998) as junior synonyms, respectively, of Sundarion apicalis (Germar) and Callicentrus bonasia (Fabricius). They also considered Pyranthe frustratoria Berg a synonym of Sundarion flavomarginatum (Fairmaire).

In the present paper two new species of Sundarion are described, and taxonomic notes on another two species are provided, along with new distribution records.

\section{MATERIAL AND METHODS}

Examined specimens belong to DZUP (Museu de Entomologia Pe. J.S. Moure, Departamento de Zoologia, Universidade 
Federal do Paraná, Curitiba) and to MPEG (Museu Paraense Emílio Goeldi, Belém). Terminology follows Deirz (1975) and Creão-Duarte \& Sakakibara (1989). Photographs (Figs. 1-3) were taken with a Leica camera (DFC295) attached to a Leica stereomicroscope (M205C). Multifocal images were combined with the Leica Application Suite (version 3.4.1). Other photographs were taken with Canon EOS.

\section{TAXONOMY}

\section{Sundarion flavopiceum Creão-Duarte \& Sakakibara, sp. nov.}

Figs. 1-4, 19-20

urn:Isid:zoobank.org:act:4BA57ADC-B529-450A-98A9-D338695BA746

Diagnosis. Pitchy-brown with yellow dots on head and metopidium; sides of pronotum with large oblique yellow spot; supra-humeral horns short, triangular, slightly flattened dorso ventrally.

Measurements (in $\mathrm{mm}$ ). Female/male. Total length 11.20/10.20; length of pronotum 10.00/8.60; width of head 4.76/4.28; length of head 2.00/2.00; width of pronotum between humeral angles 4.80/4.32; distance between apices of supra-humeral processes $6.72 / 6.00$.

Description. Holotype female (Figs. 1-3). Head yellow with irregular pitchy-brown markings; pronotum pitchy-brown with yellow dots, more dispersed over metopidium, and extended to dorsum between supra-humeral horns and behind eyes; large yellow spot on each side of pronotum, more or less fusiform, oblique, extended from base of supra-humeral horns and reaching lateral margins; apex of supra-humeral horns and of posterior process piceous. Tegmina hyaline, with smoked-brown area at apex, covering second apical cell and extended to limbus. Ventral surface of thorax, part of ovipositor, coxae, and part of femora black; sides of abdomen and legs yellowish-brown.

Head triangular (Fig. 1), 2.3x wider than long; vertex almost flat, smooth, weakly sculptured and striate, coronal suture distinctly grooved; superior margin arched, slightly sinuate at middle; ocelli located just below transocular line, closer to each other than to eyes; supra-antennal ledges straight, almost horizontal; frontoclypeus ovoid, as long as wide, extended for about half its length beyond lower margins of vertex, apex rounded and hairy. Pronotum (Figs. 2-3) shiny, roughly punctured, punctures on metopidium smaller and closer to one another than those of posterior process, larger and sparse; supra-humeral processes relatively short, triangular, acute apically, slightly flattened dorsoventrally, about as long as their basal width, directed outwards, tips slightly deflected backwards, distance between tips $1.5 \mathrm{x}$ width between humeral angles; posterior process, in lateral view, highest on dorsum just after supra-humeral horns, descending in almost straight line towards apex, posterior third distinctly subulate and prismatic, extending until apex of fifth apical cell of forewings; median carina obsolete, smooth and rounded; lateral margins close and parallel to internal margins of forewings. Forewings (Fig. 2) entirely exposed; veins $\mathrm{R}$ and $\mathrm{M}+\mathrm{Cu}$ confluent basally; two discoidal cells, the external (1rst R3) much smaller; five apical cells; veins $\mathrm{s}, \mathrm{r}-\mathrm{m}$, and $2 \mathrm{~m}$-cu present. Legs with two rows of cucullate setae on ventral side of pro- and mesothoracic femur and tibia.

Male (Fig. 4). Slightly smaller than female. Dark-brown, dots and lateral spot yellowish-green. Genitalia (Figs 19-20): pygofer more or less triangular with lateral plates distinct and well developed, slightly pointed dorsally; subgenital plate elongate, about 3x longer than wide in lateral view, strongly compressed laterally; aedeagus U-shaped, slender, tapering towards apex, with minute teeth on anterior surface, and another two larger before apex; styles recurved, hook-like.

Material examined. Holotype female. BRAZIL, Pará. "Brasil Pará | Serra Norte | MANGANÊS | COL:[ETA]: NOTURNA | 27-I1986" "Brasil Pará | H. Andrade" (MPEG). Paratypes: 1 female, with same label data as the holotype, except 26-X-1985. 1 female, "GUYANE FRANÇAISE/Piste de Bélizon/PK15+20 - 19/9/2006"; 1 male, "GUYANE FRANÇAISE/Mont Itoupé/Maripassoula/ Camopi/30/II/2014. S.E.A.G." (DZUP).

Comments. This species differs greatly from others in the genus, especially in the shape of supra-humeral horns, which are short and acute, and the dark-brown coloration, with yellow dots and a large yellow spot on each side of the posterior process, closely resembling Alcmeone picea (Fairmaire, 1846). The examined male specimen is much darker than others (probably because it was collected recently), so the lateral spot and yellowish-green dots on the pronotum are more evident. The genitalia (Figs. 19-20) are similar to those of Sundarion flavum (Fairmaire, 1846) (Fig. 25), in having the subgenital plate elongate but much more compressed laterally.

\section{Sundarion marmoratum Sakakibara \& Creão-Duarte, sp. nov.}

\author{
Figs. 5-8, 21-22
}

urn:Isid:zoobank.org:act:0CE70866-109A-4FB5-A7C9-E3522847E7EB

Diagnosis. Head yellowish-brown; pronotum with same color, variegate dark-brown on metopidium and dorsum between supra-humeral horns, darker towards tips; supra-humeral horns relatively short, strongly divergent, slightly curved, tapering towards apex, abrupt and truncate with posterior angle acute; posterior process less variegated, with large whitish-yellow patch at each side, close to margin, and distinct black round spot.

Measurements (in $\mathrm{mm}$ ). Female/male. Total length $10.00 / 7.48$; length of pronotum $8.80 / 6.40$; width of head 4.60/3.60; length of head 1.60/1.44; distance between humeral angles $4.52 / 3.60$; distance between apices of supra-humeral horns 6.80/5.40.

Description. Holotype female (Figs. 5-7). Head triangular (Fig. 7), almost $4 \mathrm{x}$ wider than long, yellowish-brown, thin median line and around each ocellus, brown; surface of vertex smooth, finely striate, slightly depressed near ocelli, superior 

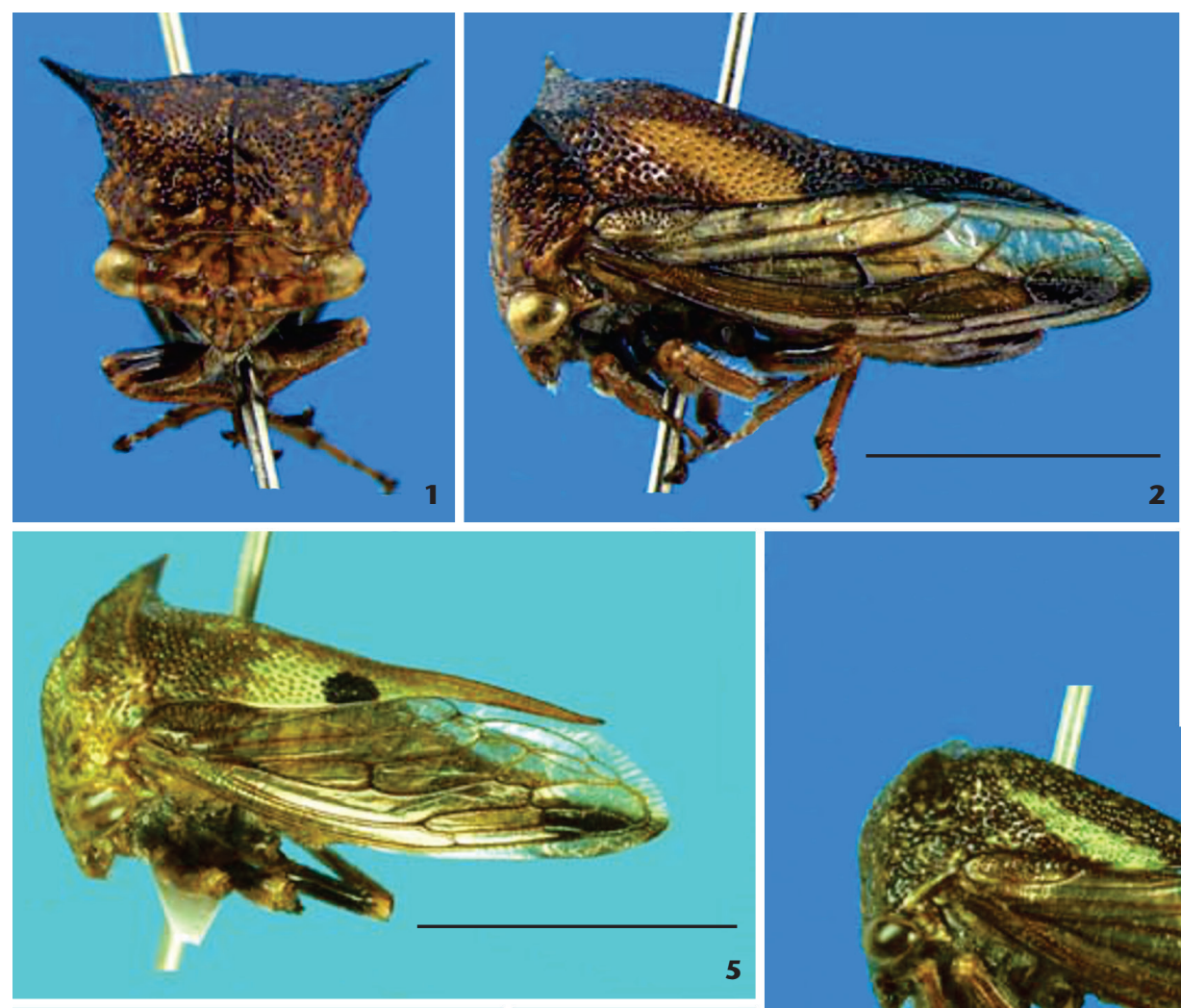

2
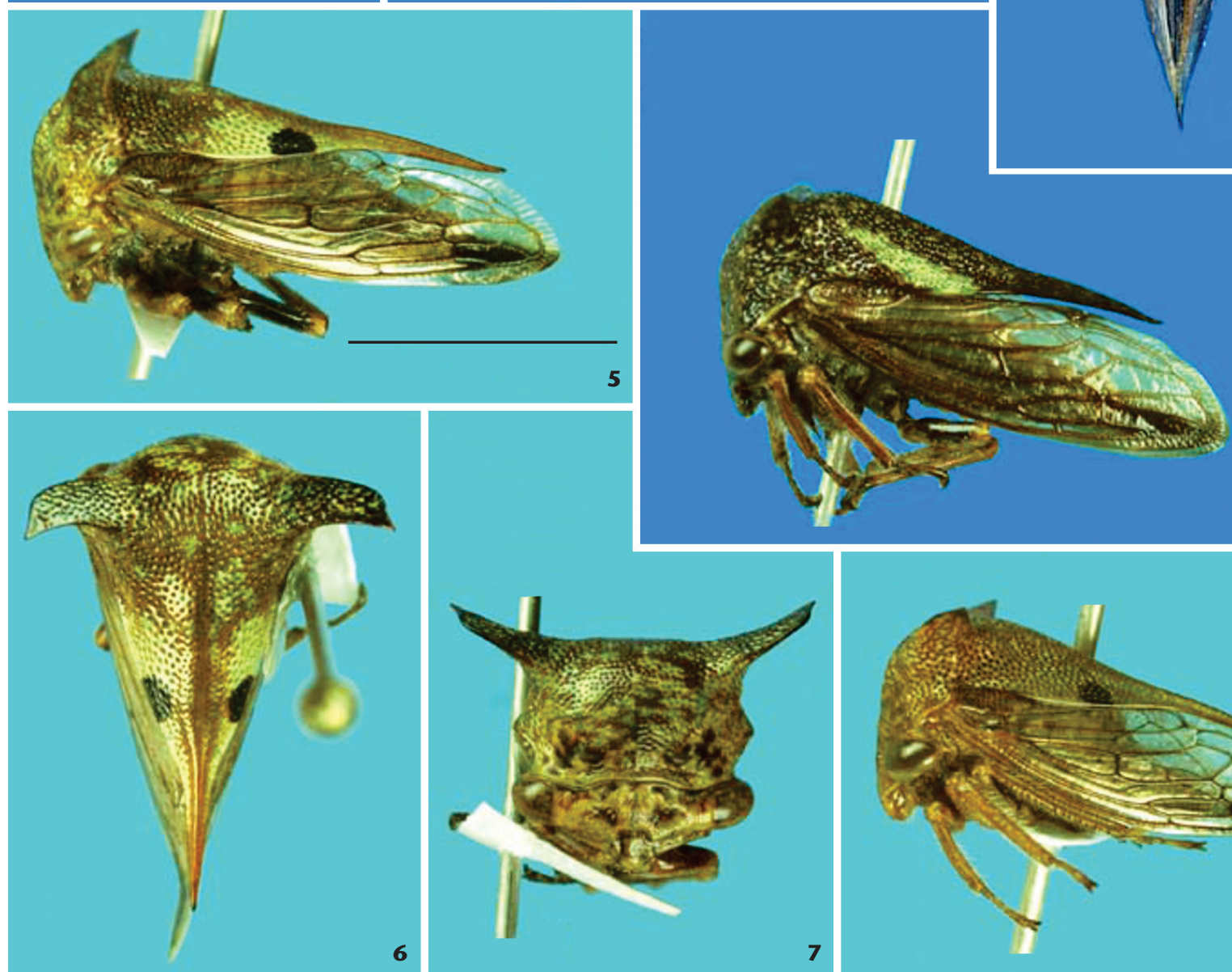

5

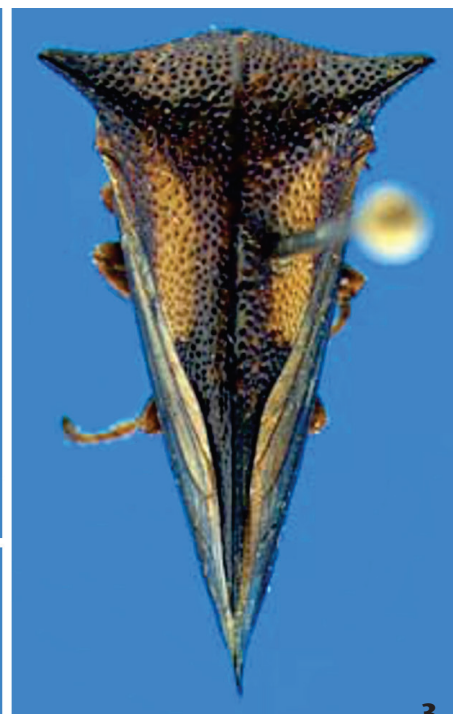

Figures 1-8. Habitus. (1-4) Sundarion flavopiceum sp. nov.: (1-3) female, holotype; (4) male; (5-8) S. marmoratum sp. nov.: (5-7) female, holotype; (8) male. Scale bar $=5 \mathrm{~mm}$.

margin widely arched; eyes ovoid; ocelli closer to each other than to eyes, situated just bellow transocular line; supra-antennal ledges flat with margins straight; frontoclypeus egg-shaped extended about half its length bellow margins of supra-antennal ledges. Pronotum (Figs. 5-7) yellowish-brown, variegated with dark-brown on metopidium and on dorsum between supra-humeral horns; supra-humeal horns dark-brown towards apex, relatively short, about $2 x$ longer than wide at base, flattened, tricarinated, strongly divergent, slightly curved backwards, narrowed to apex, truncate, with posterior angle pointed; posterior 
process low, dorsal line descending straight from metopidium to distal apex, apical third strongly constricted laterally, subulate and acuminate, terminating at level of fifth apical cell of forewings; sides of posterior process at middle with a large whitish-yellow patch close to margins enclosing distinct black spot. Forewings (Fig. 5) transparent, colorless, except brown smoked spot throughout second apical cell; five apical and two discoidal cells, transversal veins s, $\mathrm{r}-\mathrm{m}$, and $2 \mathrm{~m}$-cu present. Undersurface of thorax and legs brown; abdomen yellowish-brown.

Male (Fig. 8). Similar to female, smaller. Yellowish-castaneous, variegated on metopidium but less evident, also the whitish-yellow lateral patch with black spot not so evident. Supra-humeral horns short and almost horizontal. Genitalia (Figs. 21-22): pygofer more or less triangular with lateral plates distinct and well developed, slightly pointed dorsally; subgenital plate elongate, about $3 x$ longer than wide, more or less inflated, rounded at apex; aedeagus U-shaped, globose, with minute teeth on anterior surface; styles recurved, hook-like.

Material examined. Holotype female, "GUYANE FRANÇAISE/Montagne des Chevaux/V - 2014/Polyvie - S.E.A.G." (DZUP); Paratypes: 6 males and 4 females, with same label data (DZUP).

Comments. This species is similar to Sundarion flavum (Fairmaire) (Figs. 16-18) in its overall aspect but smaller and darker, with variegated metopidium (Fig. 8). It closely resembles Sundarion notabile Souza \& Rothéa (Figs. 9-12), both of which have similar coloration and variegated pronotum. It can be distinguished by a whitish-yellow patch on each side of the posterior process, around a black spot, which is more pronounced in females. The male genitalia of $S$. marmoratum sp. nov. are also distinctive in having the subgenital plate inflated and more rounded apically, and the aedeagus globose.

\section{Sundarion notabile Souza \& Rothéa, 2005}

\section{Figs. 9-12, 23}

Sundarion notabile Souza \& Rothéa in Creão-Duarte, Souza \& Rothéa, 2005: 95.

This species was described based on a single male specimen collected in Sinop, state of Mato Grosso. It was diagnosed as follows: "supra-humeral horns reddish-brown, short, spatulate, tricarinate, directed outwards and discreetly upwards surpassing a little the level of pronotum. Forewings entirely hyaline, with well defined veins".

Recently we found five additional specimens of this species from the type locality ( 4 males and 1 female). The following description of the female is based on this material.

Diagnosis. Head yellowish-brown; pronotum yellowish-brown, variegate dark-brown on metopidium and dorsum, dark markings more dispersed anteriorly; supra-humeral horns dark-brown, relatively short, strongly divergent, more or less parallel, abrupt and truncate at apex, posterior angle acute; posterior process with distinct black spot at each side, near lateral margins.

Measurements (in mm). Female/male. Total length
9.88/8.60; length of pronotum $8.48 / 7.40$; width of head 4.40/3.60; length of head 1.94/1.52; distance between humeral angles 4.40/3.60; distance between apices of supra-humeral horns $6.72 / 5.72$.

Description. Female (Figs. 9, 10, 12). Head triangular (Fig. 12), about twice wider than long, yellowish-brown, thin median line and around each ocellus, brown; vertex with surface smooth, slightly depressed near ocelli, superior margin widely arched; eyes ovoid; ocelli slightly closer to each other than to eyes, situated just bellow transocular line; supra-antennal ledges flat with margins straight; frontoclypeus ovoid extended about half its length bellow margins of supra-antennal ledges. Pronotum (Figs. 9-10) yellowish-brown, variegated with dark-brown, with dots more dispersed on metopidium than on dorsum; supra-humeral horns dark-brown towards apex, relatively short, about $2 \mathrm{x}$ longer than wide at base, flattened, tricarinated, strongly divergent, almost parallel-sided, truncate at apex, with posterior angle pointed; posterior process low, dorsal line descending straight from metopidium to distal apex, apical third strongly constricted laterally, subulate and acuminate, terminating at level of fifth apical cell of forewings; sides of posterior process at middle visibly clearer with a distinct blackish-brown spot close to margins which are parallel to internal margins of forewings. Forewings (Fig. 9) transparent, colorless, except brown smoked spot throughout second apical cell; five apical and two discoidal cells, transversal veins s, $\mathrm{r}-\mathrm{m}$, and $2 \mathrm{~m}$-cu present. Undersurface of thorax and legs brown; abdomen yellowish-brown.

Material examined. "BRASIL. Mato Grosso/State. Sinop xii.1976/M. Alvarenga leg." 4 males and 1 female (DZUP).

Distribution. BRAZIL, Mato Grosso.

Remarks. Larger than male, otherwise identical (Fig. 11). The color of head and pronotum varies among individuals, and may be darker with indistinct spots or lighter with contrasting dark markings; the same for the black spot on posterior process, well visible or diffused. Moreover, the apical spot of the forewings may be present or not. The male genitalia (Fig. 23) are similar to those of Sundarion flavopiceum sp. nov. (Fig. 19) with slender aedeagus, but the subgenital plate is a little shorert, not compressed laterally.

\section{Sundarion compressicornis (Fairmaire, 1846), comb. nov.}

Figs. 13-15, 24

Hemiptycha compressicornis Fairmaire, 1846: 313, Pl.6, fig. 18 (Type locality: BraziL, Bahia).

Hemiptycha truncaticornis Walker, 1858: 73 (Type locality: BRAzIL); Funkhouser, 1927: 131 (syn.) (cat.); Metcalf \& Wade, 1965: 707 (cat.); Broomfield, 1971: 381; McKamey, 1998: 155 (cat.). Hemikyptha compressicornis; Funkhouser, 1927: 131 (cat.); Metcalf \& Wade, 1965: 707 (cat.); McKamey, 1998: 155 (cat).

Measurements (in $\mathrm{mm}$ ). Female/male. Total length 11.20/8.80; length of pronotum 10.40/8.00; width of head 

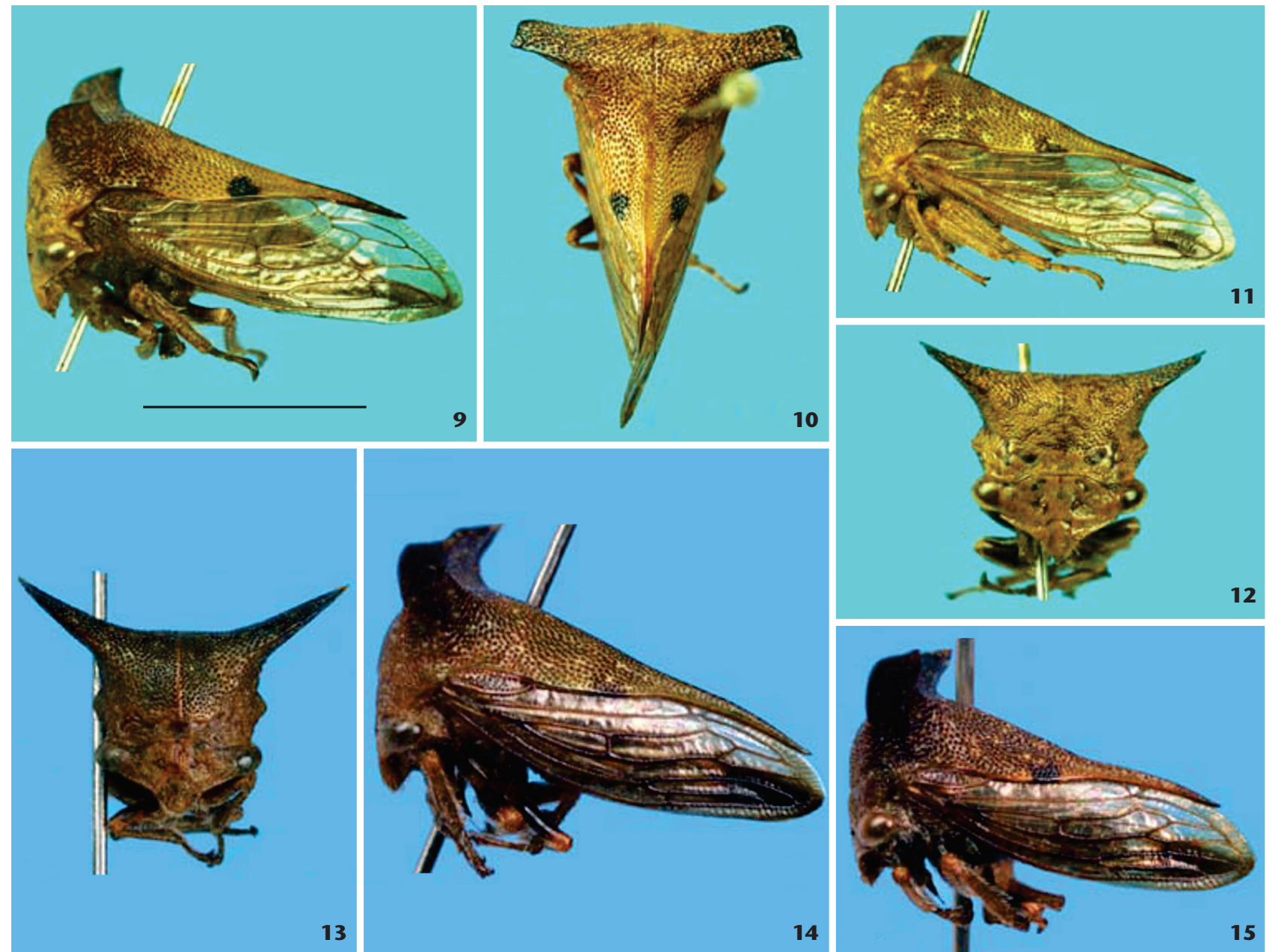

14

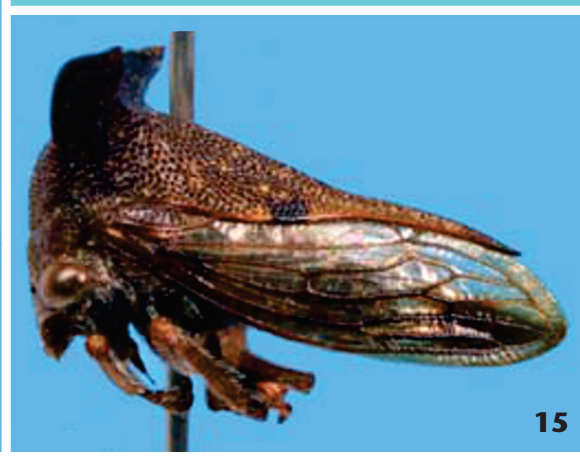

Figures 9-15. Habitus. (9-10,12) Sundarion notabile, female; (11) male; (13-15) S. compressicornis comb. nov.: (13-14) female; (15) male. Scale bar $=5 \mathrm{~mm}$.

4.80/3.68; length of head 2.08/1.60; distance between apices of supra-humeral horns $9.60 / 6.72$.

Description. Female (Figs. 13-14). Head and pronotum dark-castaneous, pronotum with sparse and small pale-yellow dots, posterior process with dark spot at middle, close to lateral margin; under surface of thorax, dorsal side of femora, and abdomen blackish-castaneous; forewings hyaline with smoked-brown patch at apex, occupying part of external discoidal cell, 1-2-3 apical cells and adjacent limbus. Head triangular (Fig. 13), twice wider than long; eyes ovoid; vertex flat, finely sculptured, superior margin widely arched above ocelli; supra-antennal ledges slightly emarginate; ocelli situated just below transocular line, nearer to each other than to eyes; frontoclypeus egg-shaped, extended about half its length beyond supra-antennal ledges. Pronotum low (Fig. 14), metopidium straight in lateral profile, posterior process straight to apex, almost attaining tips of forewings; supra-humeral horns relatively long, flattened, tricarinate, strongly divergent, slightly recurved, distance between apices about $2 \mathrm{x}$ distance between humeral angles, more or less parallel-sided, apex abruptly and obliquely truncate, with posterior angle acute; posterior process parallel to margins of forewings, apical third subulate, tectiform. Pro- and mesothoracic legs with femur and tibia with rows of cucullate setae. Forewings (Fig. 14) with two discoidal cells, five apical cells, transversal veins s, r-m, and $2 \mathrm{~m}$-cu present.

Male (Fig. 15). Very similar to female. The supra-humeral horns are little larger and stronger. Genitalia (Fig. 24): pygofer more or less triangular with lateral plates distinct and well developed, slightly pointed dorsally; subgenital plate short, about as long as pygofer, not compressed laterally; aedeagus U-shaped, slender, tapering towards apex, with minute teeth on anterior surface; styles recurved, hook-like.

Material examined. Brazil, Mato Grosso: Sinop, 3 females; Rondônia: 3 females, 5 males. French Guiana: 3 females, 2 males. (DZUP). 

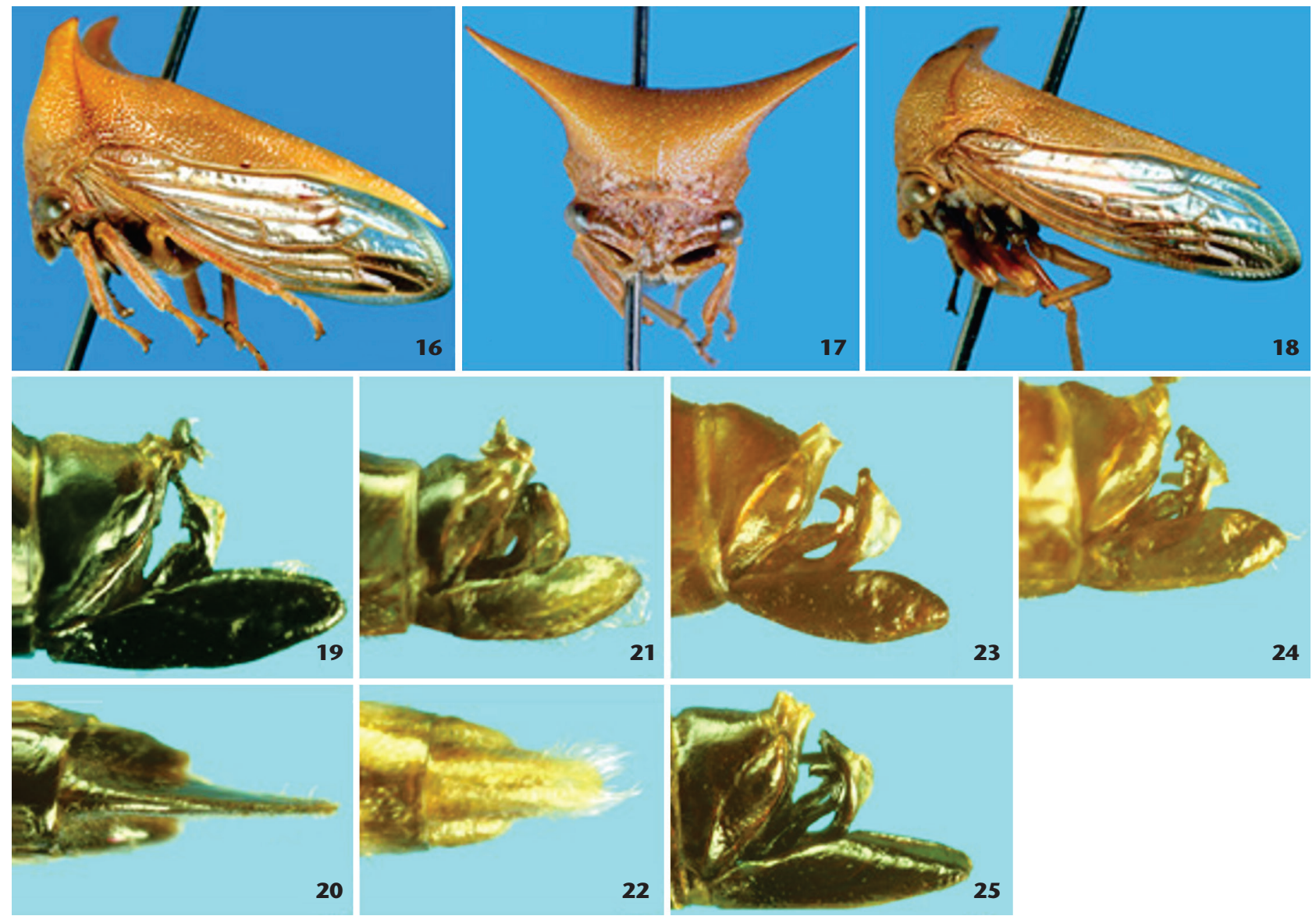

Figures 16-25. Habitus and male genitalia. (16-18) Sundarion flavum: (16-17) female; (18) male; (19-20) S. flavopiceum sp. nov.; (21-22) S. marmoratum sp. nov.; (23) S. notabile; (24) S. compressicornis comb. nov.; (25) S. flavum. Scale bar $=5 \mathrm{~mm}$.

Distribution. Brazil (Bahia, Mato Grosso, Rondônia) and French Guiana.

Remarks. FaIRMAIRE (1846) described Hemiptycha compressicornis as follows: "Testacea, cornubus humeralibus compressis, truncatis, nigris, postice nigro bimaculata". WALKER (1858) described Hemiptycha truncaticornis as follows: "Testacea, robusta; frons minima; prothorax rude punctatus, ferrugineo notatus, antice subcarinatus; cornua lateralia subobliqua, supra nigra, apice truncata; carina postica recta, nigro bimaculata, apicem versus nigrum valde attenuata, abdomen paullo superans; femora supra nigra; alae subcinereae; antica macula apicali fusca". FunkHOUSER (1927) transferred both species to Hemikyptha Metcalf, 1927, and considered $H$. truncaticornis Walker as a junior synonym of $H$. compressicornis Fairmaire. Metcalf \& WadE (1965) and McKamey (1998) did not make any changes to this classification. In the present paper, it is classified in Darnini (formerly in Hemikypthini) belonging to Sundarion Kirkaldy, 1904. The species is similar to Sundarion flavum (Fairmaire) in having supra-humeral horns well developed and strongly divergent (Fig.
17), but more robust and flattened; the lateral black spots on the posterior process are also present, though in some specimens they may be barely visible. The color of $S$. flavum, as the name suggests, is light-brown, almost yellow (Figs. 16-18).

\section{LITERATURE CITED}

BRoomfield PS (1971) A catalogue of the membracid types (Homoptera: Membracidae) in the British Museum (Natural History). Bulletin of the British Museum (Natural History), Entomology 25(8): 327-386.

ButLER AG (1878) On various genera of the homopterous family Membracidae, with descriptions of new species and a new genus in the collection of the British Museum. Cistula Entomologica 2: 337-361.

Creão-Duarte AJ, Sakakibara AM (1989) Kronides incumbens (Germar, 1835) (Homoptera, Membracidae). II. Morfologia. Revista Brasileira de Zoologia 6(1): 75-98. doi: 10.1590/ S0101-81751989000100010 
Creão-Duarte A J, de Souza OE, Rothéa RRAD (2005) Novas espécies de Sundarion Kirkaldy (Hemiptera, Membracidae). Revista Brasileira de Entomologia 49(1): 93-96. doi: 10.1590/ S0085-56262005000100009

Deitz LL (1975) Classification of the higher categories of the new world treehoppers (Homoptera: Membracidae). North Carolina Agricultural Experimental Station Technical Bulletin 225: 1-177.

Fairmaire L (1846) Revue de la tribu des Membracides. Annales de la Société Entomologique de France 4: 235-320, 479-531.

FunkHouser WD (1927). Membracidae. General Catalogue of the Hemiptera. Fasc. 1. Northampton, Smith College, 581p.

FunKHouser WD (1940) New Peruvian Membracidae (Homoptera). Journal of the New York Entomological Society 48: 275-293.

KIRKALDY GW (1904) Bibliographical and nomenclatorial notes on the Hemiptera. The Entomologist 37: 279-283.

McKamey SH (1998) Taxonomic catalogue of the Membracoidea (exclusive of leafhoppers): second supplement to fascicle I - Membracidae of the General Catalogue of the Hemiptera.

Submitted: 7 August 2015

Received in revised form: 6 October 2015

Accepted: 16 October 2015

Editorial responsibility: Gabriel L.F. Mejdalani
Memoirs of the American Entomological Institute 60: 1-377. Metcalf ZP, Wade V (1965). General Catalogue of the Homoptera. A supplement to fascicle I - Membracidae of the General Catalogue of the Hemiptera. Membracoidea. Sec. I. Raleigh, North Carolina State University, 743p.

Sakakibara AM, Creão-Duarte AJ (2006) The species of membracids described by C. Berg and M. Spinola classified in Sundarion Kirkaldy (Hemiptera, Cicadomorpha, Membracidae). Revista Brasileira de Entomologia 50(1): 31-32. doi: 10.1590/S008556262006000100003

STÅL C (1867) Bidrag till Hemipterernas Systematik. Öfversigt af Kongliga Vetenskaps-Akademiens Förhandlingar 7: 491-560.

STÅL C (1869) Bidrag till Membracidernas Kännedon. Öfversigt af Kongliga Vetenskaps-Akademiens Förhandlingar 3: 231-300.

WALKER F (1858) Insecta Saundersiana: or characters of undescribed insects in the collection of William Wilson Saunders, ESQ. - Homoptera. London, John van Voorst, 117p.

Author contributions: AJCD and AMS participated equally in the preparation of this article.

Competing interests: The authors have declared that no competing interests exist. 